\title{
Cannabis, One Health, and Veterinary Medicine: Cannabinoids' Role in Public Health, Food Safety, and Translational Medicine
}

\author{
Sivan Ritter, D.V.M., B.A. ${ }^{*}$, Lilach Zadik-Weiss, M.V.P.H., D.V.M., B.Sc.Ag., \\ L.L.B. ${ }^{2}$, Osnat Almogi-Hazan, Ph.D. ${ }^{3}$, and Reuven Or, M.D. ${ }^{3}$ \\ ${ }^{\prime}$ Independent Consultant, Tel Aviv, Israel; ${ }^{2}$ Independent Consultant, Amsterdam, The Netherlands; and \\ ${ }^{3}$ Laboratory of Immunotherapy and Bone Marrow Transplantation, Hadassah Hebrew University \\ Medical Center, Jerusalem, Israel
}

\begin{abstract}
Public health is connected to cannabis with regard to food, animal feed (feed), and pharmaceuticals. Therefore, the use of phytocannabinoids should be examined from a One Health perspective. Current knowledge on medical cannabis treatment (MCT) does not address sufficiently diseases which are of epidemiological and of zoonotic concern. The use of cannabinoids in veterinary medicine is illegal in most countries, mostly due to lack of evidence-based medicine. To answer the growing need of scientific evidence-based applicable medicine in both human and veterinary medicine, a new approach for the investigation of the therapeutic potential of cannabinoids must be adopted. A model that offers direct study of a specific disease in human and veterinary patients may facilitate development of novel therapies. Therefore, we urge the regulatory
\end{abstract}

\begin{abstract}
Abbreviations: AEA, N-arachidonoylethanolamine, anandamide; AIDS, acquired immunodeficiency syndrome; CBD, cannabidiol; CED, clinical endocannabinoid deficiency; eCB(s), endocannabinoid(s); ECS, endocannabinoid system; EFSA, European Food Safety Authority; EOs, essential oils; feed, animal feed; FDA, US Food and Drug Administration; FFFF, from feed to farm to fork to flora; FSMA, FDA Food Safety Modernization Act; GRAS, generally recognized as safe; HIV, human immunodeficiency virus; IBD(s), inflammatory bowel disease(s); MCT, medical cannabis treatment; THC, delta-9-tetrahydrocannabinol; WHO, World Health Organization.
\end{abstract}

Citation: Ritter S, Zadik-Weiss L, Almogi-Hazan O, Or R. Cannabis, One Health, and Veterinary Medicine: Cannabinoids Role in Public Health, Food Safety, and Translational Medicine. Rambam Maimonides Med J 2020;11 (1):eooo6. Review. doi:10.5041/RMMJ.10388

Copyright: (c) 2020 Ritter et al. This is an open-access article. All its content, except where otherwise noted, is distributed under the terms of the Creative Commons Attribution License (http://creativecommons.org/licenses/by/3.o), which permits unrestricted use, distribution, and reproduction in any medium, provided the original work is properly cited.

Conflict of interest: No potential conflict of interest relevant to this article was reported.

* To whom correspondence should be addressed. E-mail: Sivanritt@yahoo.com 
authorities - the ministries of health and agriculture (in Israel and worldwide) - to publish guidelines for veterinary use due to its importance to public health, as well as to promote One Health-related preclinical translational medicine studies for the general public health.

KEY WORDS: Animal models, cannabis, One Health, public health, translational medicine, veterinary medicine

\section{INTRODUCTION}

The term animal/murine model is commonly used in medical studies. The scientific paradigm of preclinical trials has not changed throughout the years. Preclinical trials using rodent models are limited in their ability to predict outcomes in human patients. Many medications developed based on rodent models fail to demonstrate clinical efficacy in humans; hence these models are neither time- nor costeffective. There are numerous reasons why laboratory animal models fail to model human reactions to drugs properly. As opposed to in humans and pets, disease does not occur naturally in animal models, and therefore the disease is not the same in the test subjects as in humans. Environmental risk factors for disease occurrence (and environmental factors influencing patients at home) are not comparable between animal models in a lab and human patients at home or in a hospital.

The One Health Initiative recognizes that both human and animal health are connected, together with the ecosystem. ${ }^{1}$ From this perspective, a better, "One Health" model for drug testing might be found in animals with naturally occurring diseases, treated as a part of their life routine, in the same environment as humans, allowing for the simultaneous development of drugs for human and animal patients, thereby reducing time to development of drugs for humans, reducing associated costs, and contributing to animal welfare. ${ }^{2}$

\section{ONE HEALTH, PUBLIC HEALTH, AND FOOD SAFETY}

The One Health Initiative mission statement emphasizes the recognition that human health, animal health, and ecosystem health are inextricably linked, and seeks to enhance cooperation and collaboration between professionals of all related fields. ${ }^{2}$ Few publications deal with the zoonotic and epidemiological aspects of public health regarding medical cannabis therapy (MCT). Public health in general-and food safety specifically-demonstrates the close relationship between veterinary and human medicine. In the fields of clinical, occupational, and environmental medicine there are also rising concerns regarding hazards of cannabis production in which there is an exposure to several contaminants including microbes, heavy metals, and pesticides. ${ }^{-5} \mathrm{~A}$ recent example of the important role of public health with regard to cannabis can be found in the Denver Department of Public Health \& Environment investigation, which found potentially unsafe levels of yeast and mold in samples of dried marijuana. This led the Denver Department of Public Health \& Environment to issue and oversee a recall process to remove potentially contaminated products from commercial circulation; to date the location list of retailers to which contaminated material was distributed includes 144 retail stores, 3 cultivation facilities, and 11 manufacturing facilities. ${ }^{6}$

\section{THE LEGAL PROBLEM OF VETERINARY MEDICAL CANNABIS IN ISRAEL}

The use of cannabinoids in veterinary medicine in Israel is illegal. Special guidelines published by the Israeli Ministry of Health set the terms for human use. There are two possible approaches that could be used to legalize cannabis for veterinary patients. The first approach would be to publish guidelines for veterinary use by the ministries of health and agriculture. These guidelines would define the following: (a) Who is allowed to prescribe cannabinoids to animals in Israel-all veterinarians versus only veterinarians authorized to prescribe cannabinoids? (b) Who will sell them-veterinary clinics versus pharmacies? (c) How will cannabinoid use be regulated to avoid abuse by owners of the animals? (d) Which animals can receive cannabinoids (addressing the issue of food-producing animals)? and (e) What is the procedure necessary to approve each veterinary cannabis prescription? A second approach would be to amend the criminal law and legalize cannabinoids, or at least cannabidiol (CBD) without restrictions. Both paths would enable veterinary patients to receive MCT, with the choice dependent on the general approach and policy of the regulator regarding cannabinoid use in Israel. 


\section{CURRENT FOOD SAFETY CONCERNS AND THEIR INTERFACES WITH PUBLIC HEALTH}

Chemicals that are present in foodstuffs can be intentionally added (i.e. food additives, or the illegal addition for adulterant purposes), are present as residues from defined uses (e.g. pesticides and veterinary drugs) or are contaminants (formed during production, processing, storage or stemming from the environment). Governments operating a food safety programme do so to ensure that food available to the population is safe and compliant with established standards. ${ }^{7}$

The term "from farm to fork" describes the importance of food safety along all stages of food production. We suggest that food safety should also address the connection between animal feed (feed), food, and the health of veterinary and human patients including the gut flora of patients-" from feed to farm to fork to flora" (FFFF). When dealing with food or feed the main concerns relate to safety and quality. Such an example can be found in the International Agency for Research on Cancer 2018 monographs, in which positive associations were observed between consumption of red meat to colorectal, pancreatic, and prostate cancers; there was also sufficient evidence to indicate that processed meat caused colorectal cancer, and a positive association was found to stomach cancer. ${ }^{8}$ These conclusions demonstrate the importance of the FFFF impact, with further studies required in order to prevent or reduce the incidence of diseases affecting morbidity and mortality rates within the general populationall of which could be translated into costs to public health due to an increasing disease burden. ${ }^{9-12}$

\section{EDIBLE CANNABINOID PRODUCTS}

Some cannabinoid products are consumed per os, which causes disagreement on their right definition; however, there is no controversy over the fact they should be legally defined and regulated. ${ }^{13-15}$ Cannabis, as it relates to public health, clearly impacts food, feed, and pharmaceuticals. Therefore, the use of phytocannabinoids should be examined from a One Health perspective. It is hard to ignore the availability of cannabis-infused foods and drinks (i.e. "edibles"). Edibles lack a legal distinct definition, yet countless products are available on the market for both humans and animals.

\section{THE LEGAL DEFINITION OF SUPPLEMENTS}

Feed and food supplements are concentrated sources of nutrients or other substances with a nutritional or physiological effect. Supplements are intended to correct nutritional deficiencies, to maintain an adequate intake of certain nutrients, and to support specific physiological functions. Supplements are not medicinal products and as such cannot claim to exert a pharmacological, immunological, or metabolic action. Their use is not intended to treat or prevent diseases in humans or to modify physiological functions. Supplements are marketed in "dose" form (i.e. pills, tablets, capsules, liquids in measured doses). They may include vitamins, minerals, amino acids, essential fatty acids, fiber, and various plants and herbal extracts. ${ }^{14,16}$ "The global dietary supplement market is projected to reach 194 billion USD by 2025," 17 and such growth projection emphasizes the need to fully understand the implications and assess possible risks to public health that might arise in a certain population.

\section{SUPPLEMENTS AND CLINICAL ENDOCANNABINOID DEFICIENCY}

Since supplements are intended to correct nutritional deficiencies, the theory of clinical endocannabinoid deficiency (CED) supports registering cannabinoids as supplements. According to Russo, ${ }^{18-20}$ humans have an underlying endocannabinoids (eCB) tone reflecting levels of $\mathrm{N}$-arachidonoylethanolamine (AEA or anandamide) and of 2-arachidonoylglycerol more familiarly known as 2-AG-their production, metabolism, abundance, receptor status, etc. Under certain conditions, congenital or acquired, eCB tone becomes deficient, producing pathophysiological syndromes. Comparable deficiency in eCB levels might be manifested similarly in certain disorders that display predictable clinical features as sequelae of this deficiency. The greatest evidence for CED is seen by its presence in migraine (AEA levels in the cerebrospinal fluid), fibromyalgia (central eCB hypofunction in the spinal cord), and irritable bowel syndrome (IBS; CB1 gene, CNR1 gene mutations). Other CEDrelated conditions include posttraumatic stress disorder, Parkinson's disease, diabetes, multiple sclerosis, and Huntington's disease. Russo has suggested that eCB may play a role in neurotransmitter deficiencies, including the acetylcholine deficiency found in Alzheimer's disease, and the serotonin and norepinephrine deficiencies found in depression..$^{18,19}$ In 
such cases, therapy options may include fatty acid amide hydrolase (commonly referred to as FAAH) inhibitors (that will raise AEA levels), exogenous cannabinoids, and integral lifestyle approaches (such as low-impact aerobic exercise regimens, dietary manipulations with probiotics, prebiotics, etc.). ${ }^{19}$

\section{ANIMAL FEED AND CANNABIS}

As part of the concern regarding chemical residues in food, a ban of antibiotic growth promoters in animal feed was implemented in EU countries in 2006. Essential oils (EOs) are an important alternative to antibiotics in animal diets, and are being further researched and used in livestock, swine, and poultry feed, as well as in aquaculture (fish farming)..$^{21-26}$ In veterinary medicine, the term phytogenic feed additives encompasses combined bioactive ingredients and flavoring substances (i.e. EOs, spices, herbs, or plant extracts) which influence the gut flora-for performance and yield enhancements (reducing oxidative stress, improving feed conversion rate, as well as improving digestibility, growth rate, and quality of derived products such as meat, eggs, dairy, and fish products)..$^{12}$ In food-producing animals, whose yield is consumed by humans on a large scale, hemp-derived feed (seed, seed cake/ meal, seed oil, whole plant) was included in the feed prior to its de-legalization and is now being carefully reintroduced, under certain technical process, into poultry feeding regimes as well as for pigs, ruminants, and fish. ${ }^{27-33}$ According to the European Food Safety Authority (EFSA), varieties allowed for hemp cultivation in Europe must not exceed 0.2\% delta-9tetrahydrocannabinol (THC), ${ }^{25}$ and according to the US Food and Drug Administration (FDA) hemp THC concentration should not exceed $0.3 \%$ on a dry weight basis. ${ }^{26}$

Regarding animal (including pet) feed, the FDA is aware of some cannabis products being marketed as animal health products. We want to stress that FDA has not approved cannabis for any use in animals, and the agency cannot ensure the safety or effectiveness of these products. 34

At this time, there are no approved food additive petitions or ingredient definitions listed ... for any substances derived from hemp, and we are unaware of any GRAS [generally recognized as safe] conclusions regarding the use of any substances derived from hemp in animal food. 35
The American Veterinary Medical Association report of January 2018 stated that the FDA had issued warning letters to companies selling products for animals containing CBD; many products did not contain the levels of CBD they claimed, with some containing $0.0025 \%$ CBD while others contained $25 \%-35 \%$ CBD. 36

\section{NUTRACEUTICALS}

Nutraceuticals were first defined by DeFelice as "Food, or parts of a food, that provide medical or health benefits, including the prevention and treatment of disease," 37 thus having a pharmacological beneficial effect on health. Nutraceuticals are not a legally defined category like food supplements (such as herbal products, pre- and probiotics, functional foods, etc.). In order to evaluate and regulate their safety and efficacy, nutraceuticals must be legally defined. There is a risk of "over-interpretation" of claimed health benefits of supplements, which may not be properly substantiated by safety and efficacy in vivo data as required for pharmaceuticals. 38,39 Despite the lack of a legally accepted definition, there is a growing number of publications regarding clinical research fields and the pharmacological beneficial effects of nutraceuticals on health-for example, bone health,40 vascular health,41,42 immunity, ${ }^{22,23,43,44}$ applied physiology, 45 dermatology, ${ }^{46}$ and in veterinary medicine.44,47,48 The lack of legal recognition for the term nutraceuticals has led to nutraceutical products, including cannabis, being registered differently, depending on specific state legislation, either as a pharmaceutical drug, or as a food/feed supplement/additive. For example: "Based on available evidence, FDA has concluded that THC and CBD products are excluded from the dietary supplement definition" 49 and "... it is a prohibited act to introduce or deliver for introduction into interstate commerce any food (including any animal food or feed) to which THC or CBD has been added." ${ }^{\circ}$ Furthermore, in November 2019 the FDA issued warning letters to 15 companies for illegally selling various products containing cannabidiol; the letter detailed safety concerns. Violations included marketing unapproved new human and animal drugs, selling CBD products as dietary supplements, and adding CBD to human and animal foods. ${ }^{51-53}$

\section{CANNABIS MEDICINAL PROFILE AND PHYTOCONSTITUENTS}

Cannabis medicinal profile phytoconstituents include phytocannabinoids, which are plant-derived 
(botanical origin) chemical compounds which interact with the (eCB) system. 47 The "entourage effect" is the total sum of all phytochemical interactions of all the phytoconstituents, differentiating from the bioactivity and effect of each component alone. Other bioactive constituents include phenolic compounds, flavonoids, and terpenes which have potential free radical scavenger activity and are omnipresent groups of plant secondary metabolites.54,55 Flavonoids (also found in fruits, vegetables, grains, bark, roots, stems, flowers, tea, and wine) have been shown to have diverse medicinal effects and act synergistically with terpenoids. ${ }^{6-61}$ Cannflavin A, B, and C are methylated isoprenoid flavones unique to cannabis. A recent study demonstrated a concentration-dependent hormetic and neuroprotective role of cannflavin-A against amyloid- $\beta$-mediated neurotoxicity, associated with an inhibition of amyloid- $\beta$ fibrillization, suggesting a line of research in regard to Alzheimer's disease, and noted that the geranylated flavonoids generally displayed a comparatively potent neurotoxicity not observed with many conventional flavonoids in vitro. ${ }^{62}$ Terpenoids are a major component of EOs, lipophilic, and can cross the blood-brain barrier. Terpenes exert diverse medicinal effects. ${ }^{55,63-75}$ Terpenoids are also flavor and fragrance components common to human and pet diets and are considered by the US FDA to be generally recognized as safe (GRAS). The use of terpenoids in food-producing animal feed is being researched due to biotechnological effects on food quality and safety as well as for performance enhancement such as weight gain; feed conversion rate; nutrient absorption; gutlining morphology; relief of intestinal immune defense in gut-associated lymphoid tissue due to antibacterial, antiviral, antifungal properties; intestinal microbiota health; meat lipid oxidation; milk composition; malodors and off-flavor in aquaculture; and palatability of feed. ${ }^{76-79}$

\section{CANNABIS, ONE HEALTH, AND FOOD SAFETY ASPECTS}

From a One Health perspective there are questions which require further investigation: Is the current food safety regulation sufficient and satisfactory in ensuring public health, given the current low use of over-the-counter bioactive molecules? Do relative costs (also for the end-user) versus public health concerns justify registering all products containing bioactive molecules as pharmaceuticals rather than as supplements/additives? Should products contain- ing bioactive molecules above a certain limit of total ingredients be regulated separately, including cannabinoids? How should the lack of sufficient comparative science to determine the long-term effects of nutraceuticals in both human and veterinary patients be addressed? What is the advised nutrition for immunocompromised populations when considering CED (what requires base-line establishment prior to treatment)? What is the recommended food composition profile? Are there necessary supplements, or supplements that should be avoided, with concurrent treatments (i.e. citicoline ${ }^{80}$ )? Which medical considerations should be included in treatment considerations (malabsorption, maldigestion, anorexia, inflammatory bowel diseases [IBDs], etc.)? What nutritional and food-safety advice should be given along with the cannabis prescription? What are the environmental risks (risks of exposure to contaminants) that patients might share in their disease etiology? Can veterinary patients with a similar natural occurring disease shed more light on the pathology? These questions demonstrate some of the FFFF effect which needs to be considered. We urge the regulatory authorities and the policymakers to address these questions and provide suitable guidelines for cannabis-based products in view of all aspects of public health.

\section{FOOD SAFETY REQUIREMENTS}

During the 1990s, major food safety adverse events (such as the bovine spongiform encephalopathy, ${ }^{81}$ dioxin, ${ }^{82}$ and Listeria ${ }^{83}$ outbreaks) led to establishment of the Global Food Safety Initiative. 84 The Food Safety System Certification FSSC22000, ${ }^{85}$ which is a set of controls to assure food processing safety and sanitation, is now an obligatory requirement: the FDA Food Safety Modernization Act (FSMA) ${ }^{86}$ has adopted the Global Food Safety Initiative's certification, resulting in significant international trade implications on the global food supply chain-from the perspective of foreign supplier verification programs-as well as on the regulatory requirements of different markets for Hazard Analysis and Risk-based Preventive Controls programs for both human food and animal feed. 87,88

The risks of food or feed contamination are present from farm to fork. They can result from environmental contamination (pollution of water, soil, or air) and require prevention and control throughout the food chain: at the farm level (contaminated animal feed, parasites that infect food-producing animals, milk contaminated through contact with 
feces or environmental dust, animal skin and fur contaminated by feces and the environment), during slaughter (intestinal contents and fecal contamination), during processing (cross-contamination, infected employees), during preparation (improper use of utensils or working surfaces), and in storage and during distribution (cross-contamination). The risk of zoonoses (i.e. listeriosis, campylobacteriosis, salmonellosis as well as E. coli, parasitical, viral, and prion infections) via contaminated foodstuffs or through contact with infected animals or their secretions is considered to be high in products of animal origin. ${ }^{89}$

\section{NOVEL PUBLIC HEALTH AND EPIDEMIOLOGY APPLICATIONS FOR CANNABINOIDS}

Clinical indications in human patients for cannabis in Israel include oncology, gastroenterology, neuropathic pain, infectious diseases (human immunodeficiency virus [HIV]/acquired immunodeficiency syndrome [AIDS]), neurology, palliative care, and psychiatry. Interestingly, these correlate to risk groups for foodborne illness (which include patients suffering from cancer, diabetes, HIV, and other immunocompromised populations)..$^{\circ}$ According to the World Health Organization (WHO),

Unsafe food containing harmful bacteria, viruses, parasites or chemical substances, causes more than 200 diseases-ranging from diarrhoea to cancers. An estimated 600 million-almost 1 in 10 people in the worldfall ill after eating contaminated food and 420,000 die every year, resulting in the loss of 33 million healthy life years (DALYs). Diarrhoeal diseases are the most common illnesses ... causing 550 million people to fall ill and 230,000 deaths every year. ${ }^{11}$

The most common clinical presentations are gastrointestinal symptoms; however, such diseases can also involve neurological, gynecological, immunological and other symptoms. According to the EFSA, "between one third and one half of all human infectious diseases have a zoonotic origin ... about $75 \%$ of the new diseases that have affected humans ... have originated from animals or products of animal origin."92 Cannabinoids may potentially address such diseases and vice versa-epidemiological data can assist in identifying needs for further MCT research for the benefit of public health.

\section{Listeriosis}

Listeriosis severely affects pregnant females, newborns, the elderly, and immunocompromised individuals. It is widely distributed in nature; Listeria spp. can be found in soil, water, vegetation, and the feces of some animals, and it can contaminate foods. ${ }^{93}-95$ Listeriosis was the cause of death in several outbreaks (i.e. contaminated soft cheese sickened 142 people, killed 10 new-borns and 18 adults, and caused 20 miscarriages in one outbreak; in another outbreak, contaminated cantaloupes caused 33 deaths $\left.{ }^{96}\right)$. Since Listeria can thrive in cold temperatures, high-risk foods include: deli meats and ready-to-eat meat products (such as cooked, cured, and/or fermented meats and sausages), soft cheeses, and cold smoked fishery products. 95,96 Additionally, Cannabis sativa L. EOs were found to demonstrate, both in vitro and in vivo, some attenuation of Listeria monocytogenes virulence, ${ }^{97}$ which could potentially be a novel strategy to reduce antimicrobial resistance in general, as well as reducing biological contaminants in food-producing establishments.

\section{Chagas Disease}

Chagas disease/American trypanosomiasis (vectorborne disease, which is transmitted by the parasite Trypanosoma cruzi), is a zoonosis of high interest for public health and for veterinary medicine (as dogs are frequently infected with $T$. cruzi); prevalence of $T$. cruzi infection is associated with increased risk of Chagas disease in humans. ${ }^{86,88}$

According to the WHO,

about 6 million to 7 million people ... worldwide are estimated to be infected with ... the parasite that causes Chagas disease ... Up to $30 \%$ of chronically infected people develop cardiac alterations and up to $10 \%$ develop digestive, neurological or mixed alterations ... Blood screening is vital to prevent infection through transfusion and organ transplantation. ${ }^{8}$

Cannabinoid compounds have been shown to inhibit parasite proliferation, growth, and invasion. ${ }^{99}$ Trypanosoma cruzi invades cardiac cells via calcium-dependent $\mathrm{G}$ protein-coupled pathways and may lead to carditis, which may be of autoimmune origin: "cannabinoids can block cardiac cell puncture repair mechanisms, thereby inhibiting trypanosome invasion as predicted by the mode of drug ac- 
tion, but also inhibit immune cell effector functions, offsetting the benefit of inhibition parasite cell invasion." 100 The Pan American Health Organization Panama country report stated that the highest morbidity was due to hypertension and that new cancers was third highest; the leading causes of mortality included malignant neoplasms, followed by ischemic heart diseases and by cerebrovascular diseases..$^{101,102}$ However, it is not yet known if there is a correlation between possible outcomes of chronic Chagas infections and cardiovascular morbidity and mortality rates. Chagas disease in dogs is also of high prevalence in Latin America, and cardiac alterations are often present. ${ }^{103-106}$ This suggests that a translational medicine study of both veterinary patients and disease progress in a natural occurring disease, and of human patients, may provide a better understanding of the disease and contribute to the development of novel treatments.

\section{Leishmaniasis and Malaria}

Translational studies of leishmaniasis in both human and veterinary patients offer great potential, since the condition is endemic in 88 countries (including Europe ${ }^{107}$ and Israel ${ }^{108-111}$ ) and on four continents: "an estimated 12 million cases of leishmaniasis exist worldwide with an estimated number of 1.5-2 million new cases occurring annually; $1-1.5$ million cases of cutaneous leishmaniasis and 500,000 cases of visceral leishmaniasis." ${ }^{112}$ Leishmania is becoming more urban and peri-urban and is not limited to rural areas. In Europe it is also important to note the impact caused by the influx of refugees mostly from Syria; the high infection rates noticed in refugee camps indicate an increased risk of infection among the local population. ${ }^{112-121}$ In addition, the number of cases of Leishmania/HIV co-infection has increased in recent years. ${ }^{112}$ Interestingly, Cannabis sativa plants were consumed by blood-sucking phlebotomine sand flies, the primary vectors of Leishmania, much more frequently than expected (i.e. since both sexes of flies consume plant-derived sugar meals, it is probable that $C$. sativa is highly attractive to sand flies). ${ }^{122}$ Some studies suggest that the EOs (especially terpenoids) are the primary phytoconstituents responsible for arthropod deterrence. ${ }^{123}$ Nevertheless, other polyphenolic compounds were found to have an antileishmanial effect ${ }^{124}$ : THC was found to exert some nominal deterrence; as it is toxic to insects, ${ }^{123}$ it might be a possible alternative to current insecticides, pesticides, and repellants. However, there are few studies on this topic. Nevertheless, it was noted that 5-acetyl-4-hydroxycannabigerol displayed strong anti-leishmanial activity, ${ }^{125}$ and that $1^{\prime}$ S-hydroxycannabinol activity was found to have a moderate anti-methicillin-resistant Staphylococcus aureus effect, a moderate anti-leishmanial effect, and mild anti-malarial activity against Plasmodium falciparum, which transmits malaria. ${ }^{126}$ Malaria is another zoonosis with great research potential as very few cannabis studies couple public health with veterinary medicine (in 2017 alone, there were 219 million cases and 435,000 deaths, with allocated resources of US $\$ 3.1$ billion). ${ }^{127-131}$

\section{Multiple Myeloma}

With regard to multiple myeloma, the epidemiological data trends in Latin America are most interesting. Increasing mortality has been verified in seven countries. Identified risk factors included age over 60 years old, male sex, and ethnicity, as well as occupational and environmental exposure to benzene, pesticides, dichlorodiphenyltrichloroethane, commonly known as DDT, and petroleum derivatives. ${ }^{132}$ A case-control study conducted in Uruguay demonstrated that red meat, salted meat, and milk were positively associated with risk of lymphoid cancers, and that plant foods, particularly total fruits, and alcoholic beverages were protective, thereby concluding that these foods could play a significant role in the etiology of lymphoid malignancies, as part of the FFFF effect. ${ }^{133}$ Designated cannabinoid formulations for treatment of multiple myeloma are currently being patented. ${ }^{134-137}$ Among other possible multiple myeloma risk factors were overweight and obesity, low fish and green vegetable consumption, AIDS, and herpes zoster infection, ${ }^{132}$ which relate conceptually to CED. Different fatty acids react differently to cytotoxic effects of drugs; therefore, there is a need to consider the interactions of different fatty acids-whether as food or as supplements (which potentially may be aimed to correct CED)with concurrent treatments in two aspects: (a) regarding the effects of different fatty acids on cytotoxic effects of drugs; and (b) regarding the negative effects of drugs on antitumor actions of specific fatty acids. ${ }^{138}$

Furthermore, a recent study found that cannabinoid-based treatments suppress rather than provoke lymphocyte proliferation; influence cytokine secretion; and that pure cannabinoids exhibit a superior effect in vitro, but that in a syngeneic transplantation model THC-high and CBD-high cannabis extracts treatment reduced the severity of graft ver- 
sus host disease, and improved survival significantly better than pure cannabinoids. ${ }^{139}$

Multiple myeloma is an uncommon lymphoproliferative disease reported in several species including dogs, cats, and horses. ${ }^{140-143}$ It differs between species and is considered a heterogeneous disease with a different prognosis, clinical course, and response to therapy both within and between species. ${ }^{141}$ Veterinary patients diagnosed with multiple myeloma could potentially help overcome the lack of success in translating promising results in rodents and in other laboratory species.

\section{Neurogenerative and Geriatric Diseases}

The increased prevalence of chronic diseases, especially neurogenerative and geriatric diseases, is attributed to the increased life expectancy of both humans and of pets. Geriatric conditions such as cognitive dysfunction syndrome, age-associated decline in renal function, and impairment of cellmediated immune function have been studied in veterinary patients (including the additional challenge of under-diagnoses of geriatric pets as being truly geriatric)..$^{144^{-151}}$ Pets have shorter lifespans and experience a more rapid progression of diseases, making the study of natural occurring diseases in veterinary patients relatively expeditious compared to in humans, as well as more cost-effective.

\section{VETERINARY MEDICINE AND MEDICAL CANNABIS THERAPY}

Veterinary medicine is lagging behind human medicine with regard to MCT due to the lack of sufficient evidence-based studies. Very few studies have been published, and most of them relate to CBD. ${ }^{152-156}$ Nevertheless, there are many anecdotal case studies about successful cannabinoid treatment in pets for similar indications in humans. Additionally, some veterinary physicians are biased against MCT, which could be associated with the lack of approved MCT training for professionals and students. ${ }^{157}$ In parallel to a growing demand from pet owners for cannabisin part due to the industry-driven market-there is an expanding availability of pet-edible cannabinoidbased products. As mentioned above, Israeli legislation prohibits veterinarians from prescribing, dispensing, or recommending cannabinoid-based products to animals. The market projection for CBD pet products in the US alone has been noted to be $7 \%$ out of a forecast of US $\$ 24$ billion annual sales, ${ }^{15} 8$ indicating a need for veterinary training since ani- mals are already receiving these products from their owners without proper medical supervision. A significant correlation was found between the number of medical marijuana licenses and marijuana toxicosis in pets (via ingestion of edibles [ 66\%], of plant material [ 19\%], and of medical cannabis preparations and/or prescription medications such as dronabinol and nabilone [ 9\%] ${ }^{159}$ ). Ingestion of THCcontaining edibles has resulted in two deaths. ${ }^{160}$ However, the reported cases had become further complicated, and the exact cause of death was not determined; hence it was concluded that no deaths associated with marijuana had been reported. ${ }^{159}$ It is worth noting that children often share the same risks as household pets, including exposure to toxicants.

\section{The Endocannabinoid System in Animals}

Numerous scientific publications exist regarding the endocannabinoid system (ECS) in various laboratory animal species; these publications support safety and therapeutic potential-which could be actually translated to any vertebrate species, thus representing the idea of translational medicine in regard to the ECS. The ECS has been described in invertebrates, ${ }^{161}$ including molluscs, ${ }^{162}$ protozoa, ${ }^{163,164}$ nematodes, onychophorans, crustaceans, ${ }^{165}$ and sea-urchins, ${ }^{166}$ and some species of cnidarians ${ }^{165,168}$; in lower vertebrates, ${ }^{161}$ including amphibia (salamanders, frogs) and other aquatic organisms ${ }^{161}$ (such as goldfish, ${ }^{167}$ zebra-fish, ${ }^{169}$ ); and in poultry ${ }^{161}$ (pigeons, ${ }^{170}$ chickens, zebra-finch). Salzet and colleagues noted that the "Cannabinoid system in all probability originated in 'simple' and primitive animals to control physio pathological responses, either similar or entirely different from those that are modulated by endocannabinoids in higher vertebrates and mammals"161 and that "Anandamide, by acting at CB1-like receptors, seems to induce often similar responses in both mammalian and invertebrate cells, particularly for what concerns the modulation of neurotransmitter release and action and the control of immune cell function [emphasis added]." ${ }^{171}$ Differences of cannabinoid receptors' density and distribution in animals ${ }^{172-174}$ can account for therapeutic effects in animal models that do not translate well into human models.

It is important to note species differences, such as the case regarding the recently identified human GABAergic interneuron subtypes called "rosehip cells," which present an immunohistochemical profile not seen in rodents, and which, despite previous studies on cortical interneurons, showed functional 
presynaptic expression of CB1r in rodents; application of CB1r antagonist was ineffective in modulating rosehip cell-evoked inhibitory postsynaptic potentials. ${ }^{175}$ Interspecies differences in eCB signaling were also found, suggesting a species profile of eCB signaling from the highest to lowest: rat > chicken $>$ mouse $>[$ human $=\operatorname{dog}]$. The highest signaling was noted in the rat, in which cannabis extracts induced reliable epileptiform convulsions and caused clear signaling down-regulation. The lowest signaling was noted in the dog, in which seizures did not occur (ataxia, tremors, hypoactivity, and other central nervous system signs were observed $\left.{ }^{176}\right) .{ }^{177}$

Cannabis intoxication in pets most commonly affects dogs (96\%) and is uncommon in cats (3\%).178 The minimum lethal oral THC dose for dogs is more than $3 \mathrm{~g} / \mathrm{kg} \cdot{ }^{176,179}$ The median lethal dose, commonly known as LD5o, has not been established in dogs or cats. ${ }^{179}$ Onset of clinical signs is within minutes (via inhalation) and about 60 minutes (per os). The biological half-life is 30 hours, and excretion is within $5^{-15}$ days ( $85 \%$ in feces and $15 \%$ in urine); recovery post ingestion is within 24 hours in most cases but can be up to 72 hours. ${ }^{159,176,179}$

\section{Veterinary Medicine, Translational Medicine, and Medical Cannabis \\ Treatment}

The goal of translational medicine according to the European Society for Translational Medicine is:

... to combine disciplines, resources, expertise, and techniques within its three main pillars which are bench-to-bedside, bedsideto-bench and community; in order to promote enhancements in prevention, diagnosis, and therapies. ${ }^{180,181}$

Cannabinoids can be used in human medicine to treat many medical conditions, such as for anxiety disorders, as antiemetics, for modulation of blood pressure and heart rate, and in asthma, inflammation, cancer, and diabetes. However, we have not found published research regarding those uses in veterinary patients. Due to legal issues, cannabinoids cannot be used in veterinary medicine in Israel. In some countries MCT is available for veterinary patients, and there is some research demonstrating its beneficial effect.

Cannabinoids have been shown to ameliorate pain associated with osteoarthritis in dogs. ${ }^{153}$ Canine osteoarthritis is associated with hip dysplasia, as well as with low back pain. It is generally common in large-breed dogs, with a predisposition in certain breeds which display a higher incidence. ${ }^{182-186}$ In humans, treatment of low back pain with MCT has been found to be advantageous as compared to standardized analgesic therapy. ${ }^{187}$ These similarities warrant further dual veterinary-human research. ${ }^{188}$ Cannabidiol was also evaluated for seizure reduction in epilepsy in dogs, although the results were preliminary and require further research. ${ }^{146,176}$ Neonatology studies in piglets have demonstrated the effects of CBD after induced acute hypoxic ischemia for lung injury, for hypothermia, and in short-term brain damage, as well as for high-dose CBD postexposure hypotension. ${ }^{189-191}$ While THC can be toxic to dogs and should be given cautiously, CBD was shown to be safe even at high doses. ${ }^{148,150}$

Autoimmune diseases and conditions involving chronic inflammation are challenging to treat in both humans and animals. The $\mathrm{CB} 2$ receptors are expressed in the immune cells of both humans and animals, therefore cannabinoids have been explored as a potential treatment for these conditions. ${ }^{139,192}$ Cannabinoid therapy has provided few improvements for these conditions, although further clinical research is needed. There is also growing interest in the potential of cannabinoids to treat HIV patients; investigation of feline immunodeficiency virus in cats could contribute to anti-retroviral therapy development. ${ }^{193-197}$ Another disease that shares similarities in veterinary and human patients is IBD. The clinical symptoms and molecular features have been found to be common in both animals and humans 198-203; however, some animal breeds are more predisposed to IBD.199,201,204-208 There is speculation that IBD evolved partially due to an inappropriate immune response to bacterial and/or dietary antigens. Food sensitivities and allergies contribute to compromised immune function. ${ }^{198,202,209-214}$ Traditional treatments often exacerbate the disorder, thus patients have increased susceptibility to gastro-intestinal lymphoma. ${ }^{194,215-221}$ Cannabinoids exert multiple effects by modulating neurotransmitters and the immune response, 139,222 and are a promising immunosuppressive and antifibrotic agent in the treatment of autoimmune disorders-and possibly IBD.

\section{SUMMARY}

The similarities between many animal and human diseases justify translational studies that will benefit all species. Such studies have the potential for better 
and more cost-effective medication development. There are many diseases common to several species that can potentially be treated with cannabis, which represent a good starting point for translational studies. It is therefore imperative that legislation is passed to enable treating animals with cannabis.

\section{REFERENCES}

1. One Health Initiative. Mission Statement. Published 2018. Available at: http://www.onehealthinitiative. com/mission.php (accessed November 7, 2019).

2. Schneider B, Balbas-Martinez V, Jergens AE, Troconiz IF, Allenspach K, Mochel JP. Model-based reverse translation between veterinary and human medicine: the One Health Initiative. CPT Pharmacometrics Syst Pharmacol 2018;7:65-8. CrossRef

3. Davidson M, Reed S, Oosthuizen J, et al. Occupational health and safety in cannabis production: an Australian perspective. Int J Occup Environ Health 2018;24:75-85. $\underline{\text { CrossRef }}$

4. Green BJ, Couch JR, Lemons AR, et al. Microbial hazards during harvesting and processing at an outdoor United States cannabis farm. J Occup Environ Hyg 2018;15:430-40. CrossRef

5. Dryburgh LM, Bolan NS, Grof CPL, et al. Cannabis contaminants: sources, distribution, human toxicity and pharmacologic effects. Br J Clin Pharmacol 2018; 84:2468-76. CrossRef

6. Denver Department of Public Health \& Environment (DDPHE). Bonsai cultivation voluntarily recalls retail marijuana, retail marijuana products due to presence of yeast/mold. Published 2019. Available at: https://marijuanaretailreport.com/bonsaicultivation-voluntarily-recalls-retail-marijuanaretail-marijuana-products-due-to-presence-of-yeastmold/ (accessed January 21, 2020).

7. World Health Organization (WHO). International Food Safety Authorities Network (INFOSAN)-monitoring for chemicals in foods monitoring for chemicals in foods summary notes; 2009. Available at: https://www.who.int/foodsafety/fs management/N o 01 Chem Maro9 en.pdf (accessed January 20, 2020).

8. International Agency for Research on Cancer (IARC) Working Group on the evaluation of carcinogenic risks to Humans. Red meat and processed meat. IARC Monographs on the Evaluation of Carcinogenic Risks to Humans Volume 114. Lyon, France: International Agency for Research on Cancer (IARC); 2018. Available at: https://publications.iarc.fr/BookAnd-Report-Series/Iarc-Monographs-On-TheIdentification-Of-Carcinogenic-Hazards-ToHumans/Red-Meat-And-Processed-Meat-2018 (accessed January 8, 2020).
9. Silva DAS, Tremblay MS, Souza MFM, Mooney M, Naghavi M, Malta DC. Mortality and years of life lost by colorectal cancer attributable to physical inactivity in Brazil (1990-2015): findings from the global burden of disease study. PLoS One 2018;13:e0190943. CrossRef

10. GBD 2017 Colorectal Cancer Collaborators. The global, regional, and national burden of colorectal cancer and its attributable risk factors in 195 countries and territories, 1990-2017: a systematic analysis for the Global Burden of Disease Study 2017. Lancet Gastroenterol Hepatol 2019;4:913-33. CrossRef

11. Ginsberg GM, Lim SS, Lauer JA, Johns BP, Sepulveda CR. Prevention, screening and treatment of colorectal cancer: a global and regional generalized cost effectiveness analysis. Cost Eff Resour Alloc 2010;8:2. CrossRef

12. Steiner T, Syed B. Phytogenic Feed Additives in Animal Nutrition. In: Máthé Á, ed. Medicinal and Aromatic Plants of the World: Scientific, Production, Commercial and Utilization Aspects. 1st ed. New York, NY: Springer Science+Media; 2015:403-23. CrossRef

13. European Monitoring Centre for Drugs and Drug Addiction. Medical Use of Cannabis and Cannabinoids: Questions and Answers for Policymaking. Luxembourg: Publications Office of the European Union; 2018. CrossRef

14. Santini A, Cammarata SM, Capone G, et al. Nutraceuticals: opening the debate for a regulatory framework. Br J Clin Pharmacol 2018;84:659-72. CrossRef

15. European Monitoring Centre for Drugs and Drug Addiction. Cannabis policy: status and recent developments. Available at:

http://www.emcdda.europa.eu/publications/topicoverviews/cannabis-policy/html en (accessed January 8, 2020).

16. US Food and Drug Administration (FDA). Dietary Supplement Products \& Ingredients. Published 2017. Available at: https://www.fda.gov/food/dietarysupplements/dietary-supplement-productsingredients (accessed November 26, 2019).

17. Grand View Research Inc. Dietary Supplements Market Worth \$194.63 Billion By 2025 | CAGR 7.8\%. Published 2019. Available at:

https://www.grandviewresearch.com/press$\underline{\text { release/global-dietary-supplements-market }}$ (accessed November 10, 2019).

18. Russo EB. Clinical endocannabinoid deficiency (CECD): can this concept explain therapeutic benefits of cannabis in migraine, fibromyalgia, irritable bowel syndrome and other treatment-resistant conditions? Neuro Endocrinol Lett 2008;29:192-200. CrossRef 
19. Russo EB. Clinical endocannabinoid deficiency reconsidered: current research supports the theory in migraine, fibromyalgia, irritable bowel, and other treatment-resistant syndromes. Cannabis Cannabinoid Res 2016;1:154-65. CrossRef

20. Smith SC, Wagner MS. Clinical endocannabinoid deficiency (CECD) revisited: can this concept explain the therapeutic benefits of cannabis in migraine, fibromyalgia, irritable bowel syndrome and other treatment-resistant conditions? Neuro Endocrinol Lett 2014;35:198-201.

21. Baiano A, Assunta Previtali M. Nutraceutical potential of selected spices, vegetables used as animal feed, and agri-food wastes. MOJ Food Processing \& Technology 2018;6:362-6. CrossRef

22. Stevanović ZD, Bošnjak-Neumüller J, Pajić-Lijaković I, Raj J, Vasiljević M. Essential oils as feed additivesfuture perspectives. Molecules 2018;23:1717. $\underline{\text { CrossRef }}$

23. Kilcawley K, Faulkner H, Clarke H, O’Sullivan M, Kerry J. Factors influencing the flavour of bovine milk and cheese from grass based versus non-grass based milk production systems. Foods 2018;7:E37. CrossRef

24. Lakhani N, Lakhani P. Plant secondary metabolites as a potential source to inhibit methane production and improve animal performance. Int J Chem Stud 2018; 6:3375-9.http://www.chemijournal.com/archives/ 2018/vol6issue3/PartAW/6-3-425-872.pdf (accessed November 7, 2019).

25. Serrano E, Cornu A, Kondjoyan N, Agabriel J, Micol D. Traceability of grass feeding in beef: terpenes, 2,3octanedione and skatole accumulation in adipose tissue of young bulls. Animal 2011;5:641-9. CrossRef

26. Wenk C. Herbs and botanicals for monogastric animals. Asian-Aust J Anim Sci 2003;16:282-9.

27. EFSA Panel on Additives and Products or Substances used in Animal Feed (FEEDAP). Scientific opinion on the safety of hemp (Cannabis genus) for use as animal feed. EFSA J 2011;9:2011 CrossRef

28. Štastník O, Filip K, Hana S, et al. The effect of hempseed cakes on broiler chickens performance parameters. In: International Ph.D. Students Conference on MendelNet; 2015. Available at: https://www.researchgate.net/publication/28371530 6_THE_EFFECT_OF_HEMPSEED_CAKES_ON_B ROILER_CHICKENS_PERFORMANCE_PARAMET ERS (accessed January 8, 2020).

29. Stastnik O, Karasek F, Stenclova H, et al. The effect of hemp by-products feeding on gut microbiota and growth of broiler chickens. In: International Ph.D. Students Conference on MendelNet; 2016. Available at: https://www.researchgate.net/publication/30977281 9 THE EFFECT OF HEMP BY-
PRODUCTS_FEEDING_ON_GUT_MICROBIOTA AND_GROWTH_OF_BROILER_CHICKENS

(accessed November 19, 2019).

30. Silversides FG, LefranÇois MR. The effect of feeding hemp seed meal to laying hens. Br Poult Sci 2005; 46:231-5. $\underline{\text { CrossRef }}$

31. Mahmoudi M, Farhoomand P, Nourmohammadi R. Effects of different levels of hemp seed (Cannabis sativa L.) and dextran oligosaccharide on growth performance and antibody titer response of broiler chickens. Ital J Anim Sci 2015;14:3473. CrossRef

32. Kalmendal R. Hemp seed cake fed to broilers. Swedish Univ Agric Sci Dep Anim Nutr Manag 2008:4-15. Available at:

https://hemptechglobal.com/resources/Hemp seed cake fed to broilers_-_R Kalmendal.pdf

(accessed January 8, 2020).

33. Sloss A. A feasibility study of industrial hemp on Virginia commercial poultry production. Senior Honors Projects, 2010-current. JMU Scholarly Commons 716. Published May 4, 2019. Available at: https://commons.lib.jmu.edu/honors201019/716 (accessed November 19, 2019).

34. US Food \& Drug Administration. FDA Regulation of Cannabis and Cannabis-Derived Products Including Cannabidiol. Question 24. I've seen cannabis products being marketed for pets. Are they safe? Available at: https://www.fda.gov/news-events/publichealth-focus/fda-regulation-cannabis-and-cannabisderived-products-including-cannabidiol-cbd (accessed November 10, 2019).

35. US Food \& Drug Administration. FDA Regulation of Cannabis and Cannabis-Derived Products Including Cannabidiol. Question 25. Can hemp be added to animal food? Available at: https://www.fda.gov/news-events/public-healthfocus/fda-regulation-cannabis-and-cannabisderived-products-including-cannabidiolcbd\#hempanimal (accessed January 12, 2020).

36. Buur J, Jeromin A, Powers J, et al. American Veterinary Medical Association (AVMA) council on biologic and therapeutic agents, cannabis: what veterinarians need to know; 2018. Available at: https://www.svma.sk.ca/uploads/pdf/Latest\%20Ite ms/Cannabis-What-Veterinarians-Need-to-Know.pdf (accessed November 20, 2019).

37. DeFelice SL. From Oysters to Insulin: Nature and Medicine at Odds. Secaucus, NJ: Citadel Press; 1986. https://www.semanticscholar.org/paper/FromOysters-to-Insulin\%3A-Nature-and-Medicine-atDeFelice/a64fo6of8ad6387062456be23a4767521fb7 23fb (accessed November 7, 2019). 
38. Lawrence J. Diamond in the roughage: can foods prevent and treat disease? Pharm J 2016;296:25-8. CrossRef

39. Albini A, Bassani B, Baci D, et al. Nutraceuticals and "repurposed" drugs of phytochemical origin in prevention and interception of chronic degenerative diseases and cancer. Curr Med Chem 2019;26:973-87. CrossRef

40. Pandey MK, Gupta SC, Karelia D, Gilhooley PJ, Shakibaei M, Aggarwal BB. Dietary nutraceuticals as backbone for bone health. Biotechnol Adv 2018; 36:1633-48. CrossRef

41. Di Francia R, Berretta M, Benincasa G, et al. Pharmacogenetic-based interactions between nutraceuticals and angiogenesis inhibitors. Cells 2019;8:E522. CrossRef

42. Scolaro B, Vaisar T, Fisher E, Castro I. Abstract 696: Reduced-dose statin therapy complemented with nutraceuticals alters HDL proteomics. Arterioscler Thromb Vasc Biol 2019;39(Suppl_1):A696. Available at: https://www.ahajournals.org/doi/abs/10.1161/ atvb.39.suppl 1.696 (accessed November 7, 2019).

43. Cicero AFG, Colletti A. Nutraceuticals Active on Immune System. In: Cicero AFG, Colletti A. Handbook of Nutraceuticals for Clinical Use. Cham, Switzerland: Springer International Publishing; 2018:163-79. CrossRef

44. Colitti M, Stefanon B, Gabai G, Gelain ME, Bonsembiante $\mathrm{F}$. Oxidative stress and nutraceuticals in the modulation of the immune function: current knowledge in animals of veterinary interest. Antioxidants 2019;8:E28. CrossRef

45. Ward WE, Chilibeck PD, Comelli EM, et al. Research in nutritional supplements and nutraceuticals for health, physical activity, and performance: moving forward. Appl Physiol Nutr Metab 2019;44:455-60. CrossRef

46. Souyoul SA, Saussy KP, Lupo MP. Nutraceuticals: a review. Dermatol Ther (Heidelb) 2018;8:5-16. CrossRef

47. Hartsel JA, Boyar K, Pham A, Silver RJ, Makriyannis A. Cannabis in Veterinary Medicine: Cannabinoid Therapies for Animals. In: Gupta RC, Srivastava A, Lall R, eds. Nutraceuticals in Veterinary Medicine. Cham, Switzerland: Springer International Publishing; 2019:121-55. CrossRef

48. Gupta RC, Srivastava A, Lall R, eds. Nutraceuticals in Veterinary Medicine. Cham, Switzerland: Springer International Publishing; 2019. $\underline{\text { CrossRef }}$

49. US Food \& Drug Administration. FDA Regulation of Cannabis and Cannabis-Derived Products Including Cannabidiol. Question 9. Can THC or CBD products be sold as dietary supplements? Available at: https://www.fda.gov/news-events/public-healthfocus/fda-regulation-cannabis-and-cannabisderived-products-including-cannabidiolcbd\#dietarysupplements (accessed January 12, 2020).

50. US Food \& Drug Administration. FDA Regulation of Cannabis and Cannabis-Derived Products Including Cannabidiol. Question 10. Is it legal, in interstate commerce, to sell a food (including any animal food or feed) to which THC or CBD has been added? Available at: https://www.fda.gov/news-events/publichealth-focus/fda-regulation-cannabis-and-cannabisderived-products-including-cannabidiol-cbd\#food (accessed January 12, 2020).

51. US Food and Drug Administration (FDA). FDA warns 15 companies for illegally selling various products containing cannabidiol as agency details safety concerns. Published November 2019. Available at: https://www.fda.gov/news-events/pressannouncements/fda-warns-15-companies-illegallyselling-various-products-containing-cannabidiolagency-details (accessed November 26, 2019).

52. Abernethy A, Schiller L. FDA is committed to sound, science-based policy on CBD. Food and Drug Administration. Published 2019. Available at:

https://www.fda.gov/news-events/fda-voicesperspectives-fda-leadership-and-experts/fdacommitted-sound-science-based-policy-cbd (accessed November 26, 2019).

53. US Food and Drug Administration (FDA). Warning letters and test results for cannabidiol-related products. Published 2019. Available at:

https://www.fda.gov/news-events/public-healthfocus/warning-letters-and-test-results-cannabidiolrelated-products (accessed November 26, 2019).

54. Tungmunnithum D, Thongboonyou A, Pholboon A, Yangsabai A. Flavonoids and other phenolic compounds from medicinal plants for pharmaceutical and medical aspects: an overview. Medicines 2018; 5:93. CrossRef

55. Ahmed M, Sikandar A, Iqbal M, et al. Phytochemical screening, total phenolics and flavonoids content and antioxidant activities of Citrullus colocynthis L. and Cannabis sativa L. Appl Ecol Environ Res 2019; 17:6961-79. $\underline{\text { CrossRef }}$

56. Wallace T, Cassidy A, Chung M, et al. Tea flavonoids and risk of cardiovascular and all-cause mortality: a systematic review and meta-analysis (Po6-126-19). Current Developments in Nutrition 2019;3(Suppl 1): nzz031.Po6-126-19. $\underline{\text { CrossRef }}$

57. Barrett ML, Scutt AM, Evans FJ. Cannflavin A and B, prenylated flavones from Cannabis sativa L. Experientia 1986;42:452-3. CrossRef 
58. Barron D, Ibrahim RK. Isoprenylated flavonoids-a survey. Phytochemistry 1996;43:921-82. CrossRef

59. Werz O, Seegers J, Schaible AM, et al. Cannflavins from hemp sprouts, a novel cannabinoid-free hemp food product, target microsomal prostaglandin E2 synthase-1 and 5-lipoxygenase. Pharma Nutrition 2014;2:53-60. $\underline{\text { CrossRef }}$

6o. Radwan MM, Elsohly MA, Slade D, et al. Noncannabinoid constituents from a high potency Cannabis sativa variety. Phytochemistry 2008;69:2627-33. CrossRef

61. Panche AN, Diwan AD, Chandra SR. Flavonoids: an overview. J Nutr Sci 2016;5:e47.

62. Eggers C, Fujitani M, Kato R, Smid S. Novel cannabis flavonoid, cannflavin A displays both a hormetic and neuroprotective profile against amyloid $\beta$-mediated neurotoxicity in PC12 cells: comparison with geranylated flavonoids, mimulone and diplacone. Biochem Pharmacol 2019;169:113609. CrossRef

63. Zamyad M, Abbasnejad M, Esmaeili-Mahani S, Mostafavi A, Sheibani V. The anticonvulsant effects of Ducrosia anethifolia (Boiss) essential oil are produced by its main component alpha-pinene in rats. Arq Neuropsiquiatr 2019;77:106-14.

64. Herrera-Calderon O, Santiváñez-Acosta R, PariOlarte B, Enciso-Roca E, Campos Montes VM, Luis Arroyo Acevedo J. Anticonvulsant effect of ethanolic extract of Cyperus articulatus L. leaves on pentylenetetrazol induced seizure in mice. J Tradit Complement Med 2018;8:95-9. $\underline{\text { CrossRef }}$

65. Subramenium GA, Vijayakumar K, Pandian SK. Limonene inhibits streptococcal biofilm formation by targeting surface-associated virulence factors. J Med Microbiol 2015;64:879-90. $\underline{\text { CrossRef }}$

66. Guimarães AC, Meireles LM, Lemos MF, et al. Antibacterial activity of terpenes and terpenoids present in essential oils. Molecules 2019;24:pii:E2471. CrossRef

67. Podduturi R, Petersen MA, Mahmud S, Rahman MM, Jørgensen NOG. Potential contribution of fish feed and phytoplankton to the content of volatile terpenes in cultured pangasius (Pangasianodon hypophthalmus) and tilapia (Oreochromis niloticus). J Agric Food Chem 2017;65:3730-6. $\underline{\text { CrossRef }}$

68. Li F, Zhang J, Lin M, et al. Anti-inflammatory terpenes from Schefflera rubriflora C. J. Tseng \& G. Hoo with their TNF- $\alpha$ and IL-6 inhibitory activities. Phytochemistry 2019;163:23-32. CrossRef

69. Vega RJS, Xolalpa NC, Castro AJA, González CP, Ramos JP, Gutiérrez SP. Terpenes from Natural Products with Potential Anti-inflammatory Activity. In: Perveen S, Al-Taweel A, eds. Terpenes and Terpenoids. London, UK: IntechOpen Limited; 2018. CrossRef.
70. Smith Grace SR, Girish C, Jyoti BC. Terpenoids: An Activator of "Fuel-sensing Enzyme AMPK" with Special Emphasis on Antidiabetic Activity. In: Ozturk M, Hakeem K, eds. Plant and Human Health, volume 2. Cham, Switzerland: Springer Nature; 2019:227-44. CrossRef

71. Marques FM, Figueira MM, Schmitt EFP, et al. In vitro anti-inflammatory activity of terpenes via suppression of superoxide and nitric oxide generation and the NF- $\kappa \mathrm{B}$ signalling pathway. Inflammopharmacology 2019;27:281-9. CrossRef

72. Carvalho AMS, Heimfarth L, Santos KA, et al. Terpenes as possible drugs for the mitigation of arthritic symptoms - a systematic review. Phytomedicine 2019;57:137-47. $\underline{\text { CrossRef }}$

73. Kubacka M, Librowski T, Czarnecki R, Frackowiak B, Lochyński S. Anticonvulsant and antidepressant activity of the selected terpene GABA derivatives in experimental tests in mice. Pharmacol Rep 2006; 58:936-43.

74. Ferber SG, Namdar D, Hen-Shoval D, et al. The "entourage effect": terpenes coupled with cannabinoids for the treatment of mood disorders and anxiety disorders. Curr Neuropharmacol 2019;17. [Epub ahead of print] CrossRef

75. Inoue M, Hayashi S, Craker LE. Role of Medicinal and Aromatic Plants: Past, Present, and Future. In: Perveen S, Al-Taweel A, eds. Pharmacognosy Medicinal Plants. London, UK: IntechOpen Limited; 2019. CrossRef

76. Giannenas I, Bonos E, Skoufos I, et al. Effect of herbal feed additives on performance parameters, intestinal microbiota, intestinal morphology and meat lipid oxidation of broiler chickens. Br Poult Sci 2018;59:545-53. $\underline{\text { CrossRef }}$

77. Zeng Z, Zhang S, Wang H, Piao X. Essential oil and aromatic plants as feed additives in non-ruminant nutrition: a review. J Anim Sci Biotechnol 2015;6:7. CrossRef

78. Valdivielso I, de Renobales M, Aldai N, Barron LJR. Changes in terpenoid composition of milk and cheese from commercial sheep flocks associated with seasonal feeding regimens throughout lactation. J Dairy Sci 2017;100:96-105. $\underline{\text { CrossRef }}$

79. Mahmoud MAA, Tybussek T, Loos HM, Wagenstaller M, Buettner A. Odorants in fish feeds: a potential source of malodors in aquaculture. Front Chem 2018; 6:241. CrossRef

80. Gruber SA, Sagar KA, Dahlgren MK, et al. Citicoline treatment improves measures of impulsivity and task performance in chronic marijuana smokers: a Pilot BOLD fMRI Study. Int J Neurol Neurother 2015;2:18. $\underline{\text { CrossRef }}$ 
81. Brown P, Will RG, Bradley R, Asher DM, Detwiler L. Bovine spongiform encephalopathy and variant Creutzfeldt-Jakob disease: background, evolution, and current concerns. Emerg Infect Dis 2001;7:6-16. CrossRef

82. Covaci A, Voorspoels S, Schepens P, Jorens P, Blust $\mathrm{R}$, Neels $\mathrm{H}$. The Belgian PCB/dioxin crisis- 8 years later. An overview. Environ Toxicol Pharmacol 2008; 25:164-70. $\underline{\text { CrossRef }}$

83. Centers for Disease Control and Prevention (CDC). Selected Publications. Listeria | CDC. Available at: https://www.cdc.gov/listeria/publications.html (accessed November 10, 2019).

84. The Global Food Safety Initiative (GFSI). Overview MyGFSI. The Global Food Safety Initiative (GFSI). Available at: https://mygfsi.com/who-we-are/ overview/ (accessed November 10, 2019).

85. FSSC 22000. The Foundation Food Safety System Certification 22000. Published 2018. Available at: https://www.fssc22000.com/ (accessed November 11, 2019).

86. US Food \& Drug Administration. Full Text of the Food Safety Modernization Act (FSMA). FDA. Available at: https://www.fda.gov/food/food-safety-modernization-act-fsma/full-text-food-safety-modernization-act-fsma (accessed November 10, 2019).

87. US Food \& Drug Administration. FSMA compliance dates. Available at: https://www.fda.gov/food/foodsafety-modernization-act-fsma/fsma-compliancedates (accessed November 10, 2019).

88. US Food \& Drug Administration. Center for Veterinary Medicine. CVM GFI \#245 Hazard analysis and risk-based preventive controls for food for animals. Available at: https://www.fda.gov/regulatoryinformation/search-fda-guidance-documents/cvmgfi-245-hazard-analysis-and-risk-based-preventivecontrols-food-animals (accessed November 10, 2019).

89. European Food Safety Authority (EFSA). Scientific topic: Foodborne zoonotic diseases. Available at: https://www.efsa.europa.eu/en/topics/topic/foodbor ne-zoonotic-diseases (accessed November 11, 2019).

90. US Food \& Drug Administration (FDA). People at risk of foodborne illness. Available at:

https://www.fda.gov/food/consumers/people-riskfoodborne-illness (accessed November 11, 2019).

91. World Health Organization. Food safety. Published 2019. Available at: https://www.who.int/en/newsroom/fact-sheets/detail/food-safety (accessed November 11, 2019).

92. European Food Safety Authority (EFSA). Scientific topic: Biological hazards. Available at: https://www.efsa.europa.eu/en/topics/topic/biologic al-hazards (accessed November 11, 2019).
93. Center for Food Safety and Applied Nutrition, Food and Drug Administration (FDA), US Department of Health and Human Services. Bad Bug Book Handbook of Foodborne Pathogenic Microorganisms and Natural Toxins. Available at: https://www.fda.gov/media/83271/download (accessed January 9, 2020)

94. World Health Organization (WHO). Listeriosis. Available at: https://www.who.int/news-room/fact-sheets/ detail/listeriosis (accessed November 13, 2019).

95. European Food Safety Authority (EFSA). Scientific topic: Listeria. Published 2019. Available at: https://www.efsa.europa.eu/en/topics/topic/listeria (accessed November 13, 2019).

96. Centers for Disease Control and Prevention (CDC). Listeria outbreaks. Available at:

https://www.cdc.gov/listeria/outbreaks/index.html (accessed November 13, 2019).

97. Marini E, Magi G, Ferretti G, et al. Attenuation of Listeria monocytogenes virulence by Cannabis sativa L. essential oil. Front Cell Infect Microbiol 2018; 8:293. $\underline{\text { CrossRef }}$

98. World Health Organization. Chagas disease (American trypanosomiasis). Published 2019. Available at: https://www.who.int/news-room/fact-sheets/ detail/chagas-disease-(american-trypanosomiasis) (accessed November 11, 2019).

99. Hernández-Cervantes R, Méndez-Díaz M, ProspéroGarcía Ó, Morales-Montor J. Immunoregulatory role of cannabinoids during infectious disease. Neuroimmunomodulation 2017;24:183-99. CrossRef

100. Croxford JL, Wang K, Miller SD, Engman DM, Tyler KM. Effects of cannabinoid treatment on Chagas disease pathogenesis: balancing inhibition of parasite invasion and immunosuppression. Cell Microbiol 2005;7:1592-602. CrossRef

101. Pan American Health Organization (PAHO), World Health Organization (WHO). Country report: Panama. Available at: https://www.paho.org/salud-enlas-americas-2017/?page id=145 (accessed November 11, 2019).

102. Pan American Health Organization (PAHO), World Health Organization (WHO). Panama. Leading health challenges. Available at: https://www.paho.org/ salud-en-las-americas-2017/?p=4289 (accessed November 11, 2019).

103. Rosypal AC, Cortés-Vecino JA, Gennari SM, Dubey JP, Tidwell RR, Lindsay DS. Serological survey of Leishmania infantum and Trypanosoma cruzi in dogs from urban areas of Brazil and Colombia. Vet Parasitol 2007;149:172-7. $\underline{\text { CrossRef }}$

04. Pineda V, Saldaña A, Monfante I, et al. Prevalence of trypanosome infections in dogs from Chagas disease 
endemic regions in Panama, Central America. Vet Parasitol 2011;178:360-3. CrossRef

105. Roegner AF, Daniels ME, Smith WA, et al. Giardia infection and Trypanosoma Cruzi exposure in dogs in the Bosawás biosphere reserve, Nicaragua. Ecohealth 2019;16:512-22. CrossRef

106. Jimenez-Coello M, Shelite T, Castellanos-Gonzalez A, et al. Efficacy of recombinase polymerase amplification to diagnose Trypanosoma cruzi infection in dogs with cardiac alterations from an endemic area of Mexico. Vector Borne Zoonotic Dis 2018;18:417-23. CrossRef

107. World Health Organization (WHO). Surveillance of leishmaniasis in the WHO European Region, 2016. Weekly epidemiological record 2018;93:521-540. Available at: https://apps.who.int/iris/bitstream/ handle/10665/275333/WER9340.pdf?ua=1 (accessed January 21, 2020).

108. Solomon M, Sahar N, Pavlotzky F, et al. Mucosal Leishmaniasis in travelers with Leishmania braziliensis complex returning to Israel. Emerg Infect Dis 2019;25:642-8. $\underline{\text { CrossRef }}$

109. Azmi K, Krayter L, Nasereddin A, et al. Increased prevalence of human cutaneous leishmaniasis in Israel and the Palestinian Authority caused by the recent emergence of a population of genetically similar strains of Leishmania tropica. Infect Genet Evol 2017;50:102-9. CrossRef

110. Spitzová T, Rohoušová I, Volf $\mathrm{P}$, et al. Serological evaluation of cutaneous Leishmania tropica infection in northern Israel. Am J Trop Med Hyg 2018;98:13941. CrossRef

111. Ben-Shimol S, Sagi O, Horev A, Avni YS, Ziv M, Riesenberg K. Cutaneous leishmaniasis caused by Leishmania infantum in southern Israel. Acta Parasitol 2016;61:855-8. CrossRef

112. World Health Organization (WHO). WHO report on global surveillance of epidemic-prone infectious diseases - Leishmaniasis. Published 2015. Available at: https://www.who.int/csr/resources/publications/ CSR_ISR_2000_1leish/en/ (accessed November 17, 2019).

113. Ibarra-Meneses AV, Carrillo E, Nieto J, et al. Prevalence of asymptomatic Leishmania infection and associated risk factors, after an outbreak in the south-western Madrid region, Spain, 2015. Eurosurveillance 2019;24:pii=1800379 $\underline{\text { CrossRef }}$

114. Razavinasab SZ, Sharifi I, Aflatoonian MR, et al. Expansion of urban cutaneous leishmaniasis into rural areas of southeastern Iran: clinical, epidemiological and phylogenetic profiles explored using 7SL high resolution melting-PCR analysis. Transbound Emerg Dis 2019;66:1602-10. $\underline{\text { CrossRef }}$
115. Saldanha-Elias AM, Silva MA, Silva VO, et al. Prevalence of endoparasites in urban stray dogs from Brazil diagnosed with Leishmania, with potential for human zoonoses. Acta Parasitol 2019;64:352-9. CrossRef

116. Lima ÁLM, de Lima ID, Coutinho JFV, et al. Changing epidemiology of visceral leishmaniasis in northeastern Brazil: a 25-year follow-up of an urban outbreak. Trans R Soc Trop Med Hyg 2017;111:4407. $\underline{\text { CrossRef }}$

117. Diniz LFB, de Souza CDF, do Carmo RF. Epidemiology of human visceral leishmaniasis in the urban centers of the lower-middle São Francisco Valley, Brazilian semiarid region. Rev Soc Bras Med Trop 2018;51:461-6. $\underline{\text { CrossRef }}$

118. Inceboz T. Epidemiology and Ecology of Leishmaniasis. In: Rodriguez-Morales AJ, ed. Current Topics in Neglected Tropical Diseases. London, UK: IntechOpen Limited; 2019. CrossRef

119. Cortes S, Afonso MO, Alves-Pires C, Campino L. Stray dogs and leishmaniasis in urban areas, Portugal. Emerg Infect Dis 2007;13:1431-2. CrossRef

120. Fotakis EA, Giantsis IA, Avgerinou A, et al. Identification of Leishmania species in naturally infected sand flies from refugee camps, Greece. Emerg Infect Dis 2019;25:361-364. CrossRef

121. Karakuş M, Çizmeci Z, Karabela ŞN, Erdoğan B, Güleç N. The impact of refugees on leishmaniasis in Turkey: a new Syrian/Turkish Leishmania tropica population structure described by multilocus microsatellite typing (MLMT). Parasitol Res 2019;118: 2679-87. CrossRef

122. Abbasi I, Trancoso Lopo de Queiroz A, Kirstein OD, et al. Plant-feeding phlebotomine sand flies, vectors of leishmaniasis, prefer Cannabis sativa. Proc Natl Acad Sci U S A 2018;115:11790-5. CrossRef

123. McPartland JM, Sheikh Z. A review of Cannabis sativa-based insecticides, miticides, and repellents. J Entomol Zool Stud 2018;6:1288-99. Available at: http://www.entomoljournal.com/archives/2018/vol6 issue6/PartV/6-6-173-373.pdf (accessed November 18, 2019).

124. Ogungbe IV, Erwin WR, Setzer WN. Antileishmanial phytochemical phenolics: molecular docking to potential protein targets. J Mol Graph Model 2014;48:105-117. $\underline{\text { CrossRef }}$

125. Radwan MM, ElSohly MA, Slade D, Ahmed SA, Khan IA, Ross SA. Biologically active cannabinoids from high-potency Cannabis sativa. J Nat Prod 2009; 72:906-11. CrossRef

126. Ahmed SA, Ross SA, Slade D, Radwan MM, Khan IA, ElSohly MA. Minor oxygenated cannabinoids from 
high potency Cannabis sativa L. Phytochemistry 2015;117:194-9. $\underline{\text { CrossRef }}$

127. Akinola O, Ogbeche EO, Olumoh-Abdul HA, et al. Oral ingestion of Cannabis sativa: risks, benefits, and effects on malaria-infected hosts. Cannabis Cannabinoid Res 2018;3:219-27. CrossRef

128. David TI, Adelakun NS, Omotuyi OI, et al. Molecular docking analysis of phyto-constituents from Cannabis sativa with pfDHFR. Bioinformation 2018;14:574-9. CrossRef

129. Abé H. Insecticidal activity of Cannabis sativa L leaf essential oil on the malaria vector Anopheles gambiae s.l (Giles). Int J Mosq Res 2018;5:65-74. Available at: http://www.dipterajournal.com/pdf/2018/vol5issue 4/PartA/5-3-19-653.pdf (accessed November 17, 2019).

130. World Health Organization (WHO). The world malaria report 2019. Available at: https://www.who.int/publications-detail/worldmalaria-report-2019 (accessed January 9, 2020).

131. World Health Organization (WHO). The world malaria report 2018. Available at: https://www. who.int/malaria/publications/world-malaria-report2018/en/ (accessed November 17, 2019).

132. Curado MP, Oliveira MM, Silva DRM, Souza DLB. Epidemiology of multiple myeloma in 17 Latin American countries: an update. Cancer Med 2018;7:21018. CrossRef

133. De Stefani E, Ronco AL, Deneo-Pellegrini H, et al. Meat, milk and risk of lymphoid malignancies: a casecontrol study in Uruguay. Nutr Cancer 2013;65:37583. $\underline{\text { CrossRef }}$

134. Xie X-q, Yang P, Feng R, inventors; University of Pittsburgh, Pittsburgh PA, USA, assignee. Novel cannabinoid receptor 2 (CB2) inverse agonists and therapeutic potential for multiple myeloma and osteoporosis bone diseases. United States Patent No.: US 8,772,541 B2. Date of Patent: July 8, 2014. The United States Patent and Trademark Office (USPTO). https://patentimages.storage.googleapis.com/17/3b/ 47/41b3f21b2a25bo/US8772541.pdf (accessed January 12, 2020).

135. Sinai A, Turner Z, Baruch Y, inventors; One World Cannabis Ltd, Petach Tikva, Israel, assignee. Novel cannabinoid combination therapies for multiple myeloma (MM). United States Patent Application: 0185324 A1 (July 5, 2018). The United States Patent and Trademark Office (USPTO). https:// patentimages.storage.googleapis.com/a8/96/87/d38 e1972d04337/US20180185324A1.pdf (accessed January 12, 2020).

136. Stott C, Nabissi M, inventors; GW Research Ltd, Cambridge, UK, applicant. Use of cannabinoids in the treatment of multiple myeloma. United States Patent
Application: 0190175547 (June 13, 2019). The United States Patent and Trademark Office (USPTO). https://patentimages.storage.googleapis.com/fo/da/ ac/75799.57c2fde81/US20190175547A1.pdf(accessed January 12, 2020).

137. Strong T, Rauvolfova J, Jackson E, et al. Novel formulation of cannabinoid analogues used in cancer therapy. J Clin Oncol 2018;36(15_suppl):e19536. CrossRef

138. Maor Y, Benadiba M, AlmogiHazan O, Serruya R, Or R. In vitro influence of different fatty acids on the pharmacological effect of temozolomide. J Transl Neurosci 2018;3:8. $\underline{\text { CrossRef }}$

139. Khuja I, Yekhtin Z, Or R, Almogi-Hazan O. Cannabinoids reduce inflammation but inhibit lymphocyte recovery in murine models of bone marrow transplantation. Int J Mol Sci 2019;20:668. CrossRef

140. Patel RT, Caceres A, French AF, McManus PM. Multiple myeloma in 16 cats: a retrospective study. Vet Clin Pathol 2005;34:341-52. $\underline{\text { CrossRef }}$

141. Sernberg R, Wypig J. An overview of multiple myeloma in dogs and cats. Vet Med 2009;104:468-76. http://veterinarymedicine.dvm360.com/overviewmultiple-myeloma-dogs-and-cats?id=\&pageID= $\underline{1 \& \mathrm{sk}}=\&$ date $=($ accessed November 12,2019$)$.

142. MuñozA, Riber C, Satu é K, Trigo P, Gómez-Díez M, Castejón FM. Multiple Myeloma in Horses, Dogs and Cats: A Comparative Review Focused on Clinical Signs and Pathogenesis. In: Hajek R, ed. Multiple Myeloma - A Quick Reflection on the Fast Progress. London, UK: IntechOpen Limited; 2013. CrossRef

143. Weiss DJ. A retrospective study of the incidence and the classification of bone marrow disorders in the dog at a veterinary teaching hospital (1996-2004). J Vet Intern Med 2006;20:955-61. $\underline{\text { CrossRef }}$

144. Davies M. Geriatric screening in first opinion practice - results from 45 dogs. J Small Anim Pract 2012; 53:507-13. $\underline{\text { CrossRef }}$

145. Bellows J, Center S, Daristotle L, et al. Aging in cats: common physical and functional changes. J Feline Med Surg 2016;18:533-50. $\underline{\text { CrossRef }}$

146. Landsberg GM, Malamed R. Clinical Picture of Canine and Feline Cognitive Impairment. In: Landsberg G, Madari A, Zilka N, eds. Canine and Feline Dementia: Molecular Basis, Diagnostics and Therapy. Cham, Switzerland: Springer International Publishing; 2017:1-12. CrossRef

147. Salvin HE, McGreevy PD, Sachdev PS, Valenzuela MJ. Under diagnosis of canine cognitive dysfunction: a cross-sectional survey of older companion dogs. Vet J 2010;184:277-81. CrossRef

148. Madari A, Farbakova J, Katina S, et al. Assessment of severity and progression of canine cognitive dysfunc- 
tion syndrome using the CAnine DEmentia Scale (CADES). Appl Anim Behav Sci 2015;171:138-45. CrossRef

149. Hall JA, Yerramilli M, Obare E, et al. Nutritional interventions that slow the age-associated decline in renal function in a canine geriatric model for elderly humans. J Nutr Heal Aging 2016;20:1010-23. CrossRef

150. Day MJ. Ageing, immunosenescence and inflammageing in the dog and cat. J Comp Pathol 2010; 142(suppl 1):S60-9. $\underline{\text { CrossRef }}$

151. Kumar K, Agrawal R, Pande N, Sharma S, Kumar H. Occurrence, clinico-haemato-biochemical and histopathological studies on mammary gland tumor in geriatric dogs. Pharma Innov J 2018;7:301-4. Available at: https://pdfs.semanticscholar.org/ bc4e/a8dfb44e5b7e604f2e97677d9f997c2a12eo.pdf

152. McGrath S, Bartner LR, Rao S, Packer RA, Gustafson DL. Randomized blinded controlled clinical trial to assess the effect of oral cannabidiol administration in addition to conventional antiepileptic treatment on seizure frequency in dogs with intractable idiopathic epilepsy. J Am Vet Med Assoc 2019;254:1301-8. CrossRef

153. Gamble L-J, Boesch JM, Frye CW, et al. Pharmacokinetics, safety, and clinical efficacy of cannabidiol treatment in osteoarthritic dogs. Front Vet Sci 2018; 5:165. CrossRef

154. Iffland K, Grotenhermen F. An update on safety and side effects of cannabidiol: a review of clinical data and relevant animal studies. Cannabis Cannabinoid Res 2017;2:139-54. $\underline{\text { CrossRef }}$

155. Kogan LR, Hellyer PW, Silcox S, Schoenfeld-Tacher R. Canadian dog owners' use and perceptions of cannabis products. Canadian Vet J 2019;60:749-55.

156. Bartner LR, McGrath S, Rao S, Hyatt LK, Wittenburg LA. Pharmacokinetics of cannabidiol administered by 3 delivery methods at 2 different dosages to healthy dogs. Can J Vet Res 2018;82:178-83.

157. Kogan L, Schoenfeld-Tacher R, Hellyer P, Rishniw M. US veterinarians' knowledge, experience, and perception regarding the use of cannabidiol for canine medical conditions. Front Vet Sci 2019;5:338. CrossRef

158. Gretler C, Craig G. The CBD industry is betting that pets need to chill, too. July 17, 2019, Bloomberg Businessweek. Available at: https://www. bloomberg.com/news/articles/2019-07-17/the-cbdindustry-is-betting-that-pets-need-to-chill-too (accessed November 10, 2019).

159. Brutlag A, Hommerding H. Toxicology of marijuana, synthetic cannabinoids, and cannabidiol in dogs and cats. Vet Clin North Am Small Anim Pract 2018;48: 1087-102. CrossRef

16o. Meola SD, Tearney CC, Haas SA, Hackett TB, Mazzaferro EM. Evaluation of trends in marijuana toxicosis in dogs living in a state with legalized medical marijuana: 125 dogs (2005-2010). J Vet Emerg Crit Care (San Antonio) 2012;22:690-6. CrossRef

161. Salzet M, Stefano GB. The endocannabinoid system in invertebrates. Prostaglandins Leukot Essent Fat Acids 2002;66:353-61. $\underline{\text { CrossRef }}$

162. Acosta-Urquidi J, Chase R. The effects of delta9tetrahydrocannabinol on action potentials in the mollusc Aplysia. Can J Physiol Pharmacol 1975;53:7938. $\underline{\text { CrossRef }}$

163. Zimmerman AM, Zimmerman SB. The Influence of Marihuana on Eukaryote Cell Growth and Development. In: Nahas GG, Paton WDM, Idänpään-Heikkilä JE, eds. Marihuana. Berlin, Heidelberg: Springer; 1976:195-205. CrossRef

164. McClean DK, Zimmerman AM. Action of delta 9tetrahydrocannabinol on cell division and macromolecular synthesis in division-synchronized protozoa. Pharmacology 1976;14:307-21. $\underline{\text { CrossRef }}$

165. McPartland JM, Agraval J, Gleeson D, Heasman K, Glass M. Cannabinoid receptors in invertebrates. J Evol Biol 2006;19:366-73. CrossRef

166. Schuel H, Goldstein E, Mechoulam R, Zimmerman AM, Zimmerman S. Anandamide (arachidonylethanolamide), a brain cannabinoid receptor agonist, reduces sperm fertilizing capacity in sea urchins by inhibiting the acrosome reaction. Proc Natl Acad Sci U S A 1994;91:7678-82. $\underline{\text { CrossRef }}$

167. Cottone E, Pomatto V, Cerri F, et al. Cannabinoid receptors are widely expressed in goldfish: molecular cloning of a CB2-like receptor and evaluation of $\mathrm{CB} 1$ and CB2 mRNA expression profiles in different organs. Fish Physiol Biochem 2013;39:1287-96. CrossRef

168. De Petrocellis L, Melck D, Bisogno T, Milone A, Di Marzo V. Finding of the endocannabinoid signalling system in Hydra, a very primitive organism: possible role in the feeding response. Neuroscience 1999;92: 377-87. CrossRef

169. Oltrabella F, Melgoza A, Nguyen B, Guo S. Role of the endocannabinoid system in vertebrates: emphasis on the zebrafish model. Dev Growth Differ 2017;59:194210. CrossRef

170. Breivogel CS, McPartland JM, Parekh B. Investigation of non-CB 1, non-CB 2 WIN55212-2-sensitive Gprotein-coupled receptors in the brains of mammals, birds, and amphibians. J Recept Signal Transduct 2018;38:316-26. $\underline{\text { CrossRef }}$ 
171. Salzet M, Breton C, Bisogno T, Di Marzo V. Comparative biology of the endocannabinoid system possible role in the immune response. Eur J Biochem 2000; 267:4917-27. $\underline{\text { CrossRef }}$

172. Freundt-Revilla J, Kegler K, Baumgärtner W, Tipold A. Spatial distribution of cannabinoid receptor type 1 (CB1) in normal canine central and peripheral nervous system. PLoS One 2017;12:e0181064. CrossRef

173. Ndong C, O’Donnell D, Ahmad S, Groblewski T. Cloning and pharmacological characterization of the dog cannabinoid CB2receptor. Eur J Pharmacol 2011; 669:24-31. CrossRef

174. Gebremedhin D, Lange AR, Campbell WB, Hillard CJ, Harder DR. Cannabinoid CB1 receptor of cat cerebral arterial muscle functions to inhibit L-type Ca2+ channel current. Am J Physiol 1999;276: H2085-93. CrossRef

175. Boldog E, Bakken TE, Hodge RD, et al. Transcriptomic and morphophysiological evidence for a specialized human cortical GABAergic cell type. Nat Neurosci 2018;21:1185-95. CrossRef

176. Fitzgerald KT, Bronstein AC, Newquist KL. Marijuana poisoning. Top Companion Anim Med 2013;28:8-12. CrossRef

177. Whalley BJ, Lin H, Bell L, et al. Species-specific susceptibility to cannabis-induced convulsions. Br J Pharmacol 2019;176:1506-23. CrossRef

178. Janeczek A, Zawadzki M, Szpot P, Niedzwiedz A. Marijuana intoxication in a cat. Acta Vet Scand 2018; 60:44. CrossRef

179. Donaldson CW. Marijuana exposure in animals. Vet Med 2002;97:437-41. Available at: https://www. researchgate.net/publication/289310520 Marijuana exposure in animals (accessed November 18, 2019).

180. Cohrs RJ, Martin T, Ghahramani P, Bidaut L, Higgins PJ, Shahzad A. Translational medicine definition by the European Society for Translational Medicine. New Horiz Transl Med 2014;2:86. CrossRef

181. European Patients' Academy (EUPATI). Translational medicine. Published 2015. Available at: https://www.eupati.eu/non-clinical-studies/translational-medicine/ (accessed November 25, 2019).

182. Pascual-Garrido C, Guilak F, Rai MF, et al. Canine hip dysplasia: a natural animal model for human developmental dysplasia of the hip. J Orthop Res 2018;36:1807-17. CrossRef

183. Oberbauer AM, Keller GG, Famula TR. Long-term genetic selection reduced prevalence of hip and elbow dysplasia in 60 dog breeds. PLoS One 2017;12: e0172918. CrossRef
184. Tellegen AR, Dessing AJ, Houben K, et al. Dog as a model for osteoarthritis: the FGF4 retrogene insertion may matter. J Orthop Res 2019;37:2550-60. CrossRef

185. Anderson KL, O’Neill DG, Brodbelt DC, et al. Prevalence, duration and risk factors for appendicular osteoarthritis in a UK dog population under primary veterinary care. Sci Rep 2018;8:5641. CrossRef

186. Todhunter RJ, Garrison SJ, Jordan J, et al. Gene expression in hip soft tissues in incipient canine hip dysplasia and osteoarthritis. J Orthop Res 2019;37: 313-24. CrossRef

187. Yassin M, Robinson D. Effect of adding medical cannabis to analgesic treatment in patients with low back pain related to fibromyalgia: an observational cross-over single centre study. Int J Anesth Pain Med 2017,3:2. CrossRef

188.Zeira O, Scaccia S, Pettinari L, et al. Intra-articular administration of autologous micro-fragmented adipose tissue in dogs with spontaneous osteoarthritis: safety, feasibility, and clinical outcomes. Stem Cells Transl Med 2018;7:819-28. $\underline{\text { CrossRef }}$

189. Garberg HT, Solberg R, Barlinn J, Martinez-Orgado J, Løberg EM, Saugstad OD. High-dose cannabidiol induced hypotension after global hypoxia-ischemia in piglets. Neonatology 2017;112:143-9. CrossRef

190. Lafuente H, Pazos MR, Alvarez A, et al. Effects of cannabidiol and hypothermia on short-term brain damage in new-born piglets after acute hypoxiaischemia. Front Neurosci 2016;10:323.

191. Arruza L, Pazos MR, Mohammed N, et al. Cannabidiol reduces lung injury induced by hypoxic-ischemic brain damage in newborn piglets. Pediatr Res 2017; 82:79-86. CrossRef

192. Rom S, Persidsky Y. Cannabinoid receptor 2: potential role in immunomodulation and neuroinflammation. J Neuroimmune Pharmacol 2013;8:608-20. CrossRef

193. Ponti W, Rubino T, Bardotti M, Poli G, Parolaro D. Cannabinoids inhibit nitric oxide production in bone marrow derived feline macrophages. Vet Immunol Immunopathol 2001;82:203-14. CrossRef

194. Cannon CM. Cats, cancer and comparative oncology. Vet Sci 2015;2:111-26. CrossRef

195. Siebelink KH, Chu IH, Rimmelzwaan GF, et al. Feline immunodeficiency virus (FIV) infection in the cat as a model for HIV infection in man: FIV-induced impairment of immune function. AIDS Res Hum Retroviruses 1990;6:1373-8. $\underline{\text { CrossRef }}$

196. Elder JH, Lin YC, Fink E, Grant CX. Feline immunodeficiency virus (FIV) as a model for study of Lenti- 
virus infections: parallels with HIV. Curr HIV Res 2010;8:73-80. CrossRef

197. Burkhard M, Dean G. Transmission and immunopathogenesis of FIV in cats as a model for HIV. Curr HIV Res 2003;1:15-29. CrossRef

198. Jergens AE, Simpson KW. Inflammatory bowel disease in veterinary medicine. Front Biosci (Elite Ed) 2012;4:1404-19. CrossRef

199. Kathrani A, Werling D, Allenspach K. Canine breeds at high risk of developing inflammatory bowel disease in the south-eastern UK. Vet Rec 2011;169:635. CrossRef

200.Allenspach K, Wieland B, Gröne A, Gaschen F. Chronic enteropathies in dogs: evaluation of risk factors for negative outcome. $\mathrm{J}$ Vet Intern Med 2007;21:700-8. $\underline{\text { CrossRef }}$

201. Kathrani A, House A, Catchpole B, et al. Polymorphisms in the TLR4 and TLR5 gene are significantly associated with inflammatory bowel disease in German shepherd dogs. PLoS One 2010;5:e15740. CrossRef

202. Vázquez-Baeza Y, Hyde ER, Suchodolski JS, Knight R. Dog and human inflammatory bowel disease rely on overlapping yet distinct dysbiosis networks. Nat Microbiol 2016;1:16177. $\underline{\text { CrossRef }}$

203. Cerquetella M, Spaterna A, Laus F, et al. Inflammatory bowel disease in the dog: differences and similarities with humans. World J Gastroenterol 2010;16: 1050-6. CrossRef

204. Littman MP, Dambach DM, Vaden SL, Giger U. Familial protein-losing enteropathy and protein-losing nephropathy in soft coated wheaten terriers: 222 cases (1983-1997). J Vet Intern Med 2000;14:68-80. CrossRef

205. United State Department of Agriculture. Animal and Plant Health Inspection Services (USDA:APHIS). Incidence of colic in U.S. horses. October 2001. Available at: https://www.aphis.usda.gov/animal health/ nahms/equine/downloads/equine98/Equine98_is Colic.pdf (accessed January 10,2020).

206. Schumacher J, Edwards JF, Cohen ND. Chronic idiopathic inflammatory bowel diseases of the horse. J Vet Intern Med 2000;14:258-65. CrossRef

207. Boshuizen B, Ploeg M, Dewulf J, et al. Inflammatory bowel disease (IBD) in horses: a retrospective study exploring the value of different diagnostic approaches. BMC Vet Res 2018;14:21. $\underline{\text { CrossRef }}$

208. Gough A, Thomas A, O’Neill D. Breed Predispositions to Disease in Dogs and Cats. Chichester, UK: John Wiley \& Sons, Ltd; 2018. $\underline{\text { CrossRef }}$
209. Mandigers P, German AJ. Dietary hypersensitivity in cats and dogs. Tijdschr Diergeneeskd 2010;135:70610.

210. Dandrieux JRS. Inflammatory bowel disease versus chronic enteropathy in dogs: are they one and the same? J Small Anim Pract 2016;57:589-99. CrossRef

211. Kent A. Canine chronic enteropathy. Vet Times 2017:47. Available at:

https://www.vettimes.co.uk/app/uploads/wp-postto-pdf-enhanced-cache/1/canine-chronicenteropathy.pdf (accessed January 10, 2020).

212. Willard MD. Digestive System Disorders. In: Nelson RW, Richard RW, Couto CG, eds. Small Animal Internal Medicine. 4th ed. St. Louis, MO: Mosby Elsevier; 2009:440-75.

213. Defarges A. Inflammatory Bowel Disease in Small Animals. In: MSD Manual: Veterinary Manual. Kenilworth, NJ: Merck \& Co., Inc.: 2020. Available at: https://www.msdvetmanual.com/digestivesystem/diseases-of-the-stomach-and-intestines-insmall-animals/inflammatory-bowel-disease-in-smallanimals (accessed November 24, 2019).

214. Salavati Schmitz S, Gow A, Bommer N, Morrison L, Mellanby R. Diagnostic features, treatment, and outcome of dogs with inflammatory protein-losing enteropathy. J Vet Intern Med 2019;33:2005-13. CrossRef

215. Allenspach K. Pathogenesis of IBD in Dogs. In: Proceedings of the Southern European Veterinary Conference and Congreso Nacional AVEPA. Published in IVIS with the permission of SEVC \& AVEPA; 2016. www.ivis.org (accessed November 24, 2019).

216. Moore PF, Rodriguez-Bertos A, Kass PH. Feline gastrointestinal lymphoma. Vet Pathol 2012;49:65868. $\underline{\text { CrossRef }}$

217. Louwerens M, London CA, Pedersen NC, Lyons LA. Feline lymphoma in the post-feline leukemia virus era. J Vet Intern Med 2005;19:329-35. CrossRef

218. Rissetto K, Villamil JA, Selting KA, Tyler J, Henry CJ. Recent trends in feline intestinal neoplasia: an epidemiologic study of 1,129 cases in the veterinary medical database from 1964 to 2004. J Am Anim Hosp Assoc 2011;47:28-36. CrossRef

219. Collette SA, Allstadt SD, Chon EM, et al. Treatment of feline intermediate- to high-grade lymphoma with a modified university of Wisconsin-Madison protocol: 119 cases (2004-2012). Vet Comp Oncol 2016; 14(Suppl 1):136-46. $\underline{\text { CrossRef }}$

220. Arteaga TA, McKnight J, Bergman PJ. A review of 18 cases of feline colonic adenocarcinoma treated with 
subtotal colectomies and adjuvant carboplatin. J Am Anim Hosp Assoc 2012;48:399-404. CrossRef

221. Slawienski MJ, Mauldin GE, Mauldin GN, Patnaik AK. Malignant colonic neoplasia in cats: 46 cases (1990-1996). J Am Vet Med Assoc 1997;211:878-81.
222. Zou S, Kumar U. Cannabinoid receptors and the endocannabinoid system: signaling and function in the central nervous system. Int J Mol Sci 2018;19: E833. CrossRef 